\title{
MODELING THE RELATIONSHIPS BETWEEN MOLECULAR STRUCTURE AND INHIBITION OF VIRUS- INDUCED CYTOPHATIC EFFECTS. ANTI-HIV-1 AND ANTI-H1N1 (INFLUENZA A) ACTIVITIES AS EXAMPLES
}

\author{
DIEGO A. ALARCÓN, FERNANDO GATICA-DÍAZ AND JUAN S. GÓMEZ-JERIA*
}

Department of Chemistry, Faculty of Sciences, University of Chile. P.O. Box 653, Santiago, Chile.

(Received: January 8, 2013 - Accepted: February 1, 2013)

\begin{abstract}
In this paper we tested the hypothesis that the building up of model-based methods to correlate molecular structure with the concentration required for the production of some biological effects such as giant cell formation, reduction of the number of viable cells, etc. is possible. We provide data supporting this model presenting structure-relationships results for two sets of molecules displaying inhibitory activity against some effects of HIV-1 and H1N1 viruses. The local atomic reactivity indices were calculated at the ZINDO/1 level of the theory. We found several statistically significant equations showing that some process is charge-, orbital- and/or steric-controlled. The main and most important conclusion is that the method, originally designed only for in vitro molecule-site equilibrium constants, nicely works for other properties like cytopathicity protection and cytostatic concentrations. This opens an entirely new research field and raises the possibility that this methodology be applied to other types of reports of biological activity data. We conjecture that this method is superior to the Hansch approach and that it is related in a still unknown form to the Hammett methodology.
\end{abstract}

\section{INTRODUCTION}

In the last three decades we have extended and perfected a formal method to correlate in vitro receptor affinity constants with the electronic structure and the substituent's orientational parameters of drug molecules ${ }^{1-7}$. In the field of pharmacological evaluation of biological activities, sometimes the results are reported as the inhibition of the appearance of some macroscopic changes of the biological systems under test. Good examples are the cytopathic effects (CPE). They correspond to the visible changes that show cell cultures after being infected with a virus and killed. For example, and in MDCK cells (Madin-Darby canine kidney epithelial cells) grown as a monolayer, CPE due to influenza viruses consist of "visible changes in the appearance of nuclei in infected cells, and the formation of focal enlarged granular cells or non-specific cell deterioration, followed by detachment of the swollen cells from the growing surface". HIV (Human immunodeficiency virus) causes two types of CPE: syncytia (multinucleate cells which can result from multiple cell fusions of uninuclear cells) and single cell lysis ${ }^{9}$. In both cases, the antiviral activity of the tested molecules is reported as the concentration needed to reduce by $50 \%$ the CPE.

No model-based methods ${ }^{10}$ to correlate molecular structure with the reduction of these visible macroscopic effects (VME) exist. This is a field of research of the outmost importance because the VME are employed, for example, as indicators of antiviral or antitumoral activity. In this paper, and with the use of a reasonable hypothesis, we show that the building up of this kind of models is possible. We provide data supporting this model by presenting structure-activity relationships results for two sets of molecules displaying inhibitory activity against some effects of HIV-1 and influenza H1N1 viruses.

\section{METHODS, MODEL AND CALCULATIONS}

A. Theory. As the model-based method to relate drug-receptor equilibrium constants with molecular structure has been described and applied in this Journal ${ }^{5,11-14}$ and elsewhere ${ }^{7,15-17}$, we present here only the final results. The drug-receptor affinity, $\mathrm{f}(\mathrm{DR})$, is a linear function of several local atomic reactivity indices (LARI) and has the following general form:

$$
\begin{aligned}
& \mathrm{f}(\mathrm{DR})_{i} \cong a+b M_{D_{i}}+c \log \left[\sigma_{D_{i}} /(A B C)^{1 / 2}\right]+\sum_{j}\left[e_{j} Q_{j}+f_{j} S_{j}^{E}+s_{j} S_{j}^{N}\right]+ \\
& +\sum_{j} \sum_{m}\left[h_{j}(m) F_{j}(m)+x_{j}(m) S_{j}^{E}(m)\right]++\sum_{j} \sum_{m^{\prime}}\left[r_{j}\left(m^{\prime}\right) F_{j}\left(m^{\prime}\right)+t_{j}\left(m^{\prime}\right) S_{j}^{N}\left(m^{\prime}\right)\right]+ \\
& +\sum_{j}\left[g_{j} \mu_{j}+k_{j} \eta_{j}+o_{j} \omega_{j}+z_{j} \varsigma_{j}+w_{j} Q_{j}^{\max }\right]
\end{aligned}
$$

where $M$ is the drug's mass, $\sigma$ its symmetry number and $A B C$ the product of the drug's moment of inertia about the three principal axes of rotation, $\mathrm{Q}_{\mathrm{i}}$ is the net charge of atom $i, S_{i}^{E}$ and $S_{i}^{N}$ are, respectively, the total atomic electrophilic and nucleophilic superdelocalizabilities of Fukui et al. ${ }^{18}, \mathrm{~F}_{\mathrm{i}, \mathrm{m}}$ is the Fukui index of the occupied (empty) MO m (m') located on atom i. $\mathrm{S}_{\mathrm{i}}^{\mathrm{Lm}}(\mathrm{m})$ is the atomic electrophilic superdelocalizability of MO $\mathrm{m}$ on atom i, etc. The total atomic electrophilic superdelocalizability (ESD) of atom i is defined as the sum over occupied MOs of the $\mathrm{S}_{\mathrm{i}}^{\mathrm{E}}(\mathrm{m})$ 's and the total atomic nucleophilic superdelocalizability (NSD) of atom $i$ is defined as the sum over empty MOs of the $\mathrm{S}_{\mathrm{N}}^{\mathrm{N}}(\mathrm{m})$ 's. The last bracket of the right side of Eq. 1 contains new local atomic reactivity indices obtained by an approximate rearrangement of part of the remaining terms of the series expansion employed in the model ${ }^{7}$. The local atomic electronic chemical potential of atom $i, \mu_{i}$, is defined as:

$$
\mu_{i}=\frac{E_{o c}^{*}-E_{e m}^{*}}{2}
$$

where $E_{o c}^{*}$ is the upper occupied MO located on atom with a non-zero Fukui index and $E_{e m}$ is the lowest empty MO located on atom i with a nonzero Fukui index.

The total local atomic hardness of atom $i, \eta_{i}$, is defined as:

$$
\eta_{i}=E_{e m}^{*}-E_{o c}^{*}
$$

The total local atomic softness of atom $i, \varsigma_{i}$, is defined as the inverse of the local atomic hardness. The local electrophilic index of atom $\mathrm{i}, \omega_{\mathrm{i}}$, is defined as:

$$
\omega_{i}=\frac{\mu_{i}^{2}}{2 \eta_{i}}
$$

The maximal amount of electronic charge that an electrophile may accept, $Q_{i}^{\max }$, is defined as:

$$
Q_{i}^{\max }=\frac{-\mu_{i}}{\eta_{\mathrm{i}}}
$$

These are the local atomic analogues of similar global reactivity indices currently used in today's quantum chemistry ${ }^{19-24}$. The general meaning of these local indices is: $\mu_{\mathrm{i}}$ is a measure of the tendency of an atom to gain or lose electrons; a large negative value indicates a good electron acceptor atom while a small negative value implies a good electron donor atom. The local atomic hardness can be interpreted as the resistance of an atom to exchange electrons with the environment. The local atomic electrophilic index is associated with 
the electrophilic power of an atom and includes the tendency of the electrophile atom to receive extra electronic charge together with its resistance to exchange charge with the medium. Some of these indices $\left(\eta_{i}\right.$ and $\left.\omega_{i}\right)$ have appeared in a recent QSAR study ${ }^{7}$. The central importance of Eq. 1 is that it contains only terms belonging to the drug molecules.

On the other hand, the mechanisms for the inhibition of virus-induced CPE seem no not be clear for all cases. Test molecules may exert their effect(s) at the virus surface or they may penetrate the virus and act on a molecular site. The crossing of biological membranes (like lipid membranes) can be represented approximately by the partition coefficient, $\mathrm{P}$, of the molecule. Quite a time ago Arthur Cammarata analyzed $\log \mathrm{P}$ in terms of the Klopman general model for charge and orbital-controlled reactions ${ }^{25-27}$ (Klopman's work is also the basis of our model-based method, see Ref. 3). He was able to demonstrate that $\log \mathrm{P}$ was a linear function of a similar mathematical structure than Eq. 1.

If, on the one hand, Eq. 1 represents a drug-site interaction and on the other hand Cammarata's model represents the crossing through membranes, and given that both equations are linear functions of the same LARIs, then a preliminary representation of the inhibition effects of can be obtained simply by replacing $\mathrm{f}(\mathrm{DR})$ by $\mathrm{f}(\mathrm{CPE})$.

It was shown that the moment of inertia term of Eq. 1 it can be expressed in a first approximation $\mathrm{as}^{28-30}$ :

$$
\log \left[(A B C)^{-1 / 2}\right] \approx \sum_{t} \sum_{t} m_{i, t} R_{i, t}^{2}=\sum_{t} O_{t}
$$

where the summation over $t$ is over the different substituents of the molecule, $\mathrm{m}_{\mathrm{i}}$ is the mass of the $\mathrm{i}$-th atom belonging to the $\mathrm{t}$-th substituent, $\mathrm{R}_{\mathrm{i}, \mathrm{t}}$ being its distance to the atom to which the substituent is attached. This approximation allows us to transform a molecular property into a sum of substituent properties. As the physical interpretation of these terms it was proposed that they represent the fraction of molecules attaining the proper orientation to interact with the receptor. We have called them Orientation Parameters.

Then, for $\mathrm{n}(\mathrm{i}=1, \mathrm{~N})$ molecules we have a set of simultaneous equations 1. This system of simultaneous equations holds for the atoms of the molecule directly concerned in the interaction process. Combined with the usual multiple-regression techniques, these equations can be usefully applied to estimate the relative variation of the biological activities in the family of molecules analyzed.

B. Selection of the experimental data.

From an ideal point of view a set of molecules selected to carry out a QSAR study should cover all factors that affect activity ${ }^{31}$. The vast majority of variance in the physicochemical properties of a compound is contained in the information space described generically by factors representing lipophilicity, electronic factors, and size or shape. In the case of our model, lipophilicity and electronic factors are covered by Eq. 1 and size/shape influence by the orientational parameters of Eq. 6. Unhappily, experimentalists synthesize and test groups of molecules that in general do not fully fulfill the above requirement.

Influenza A is a RNA virus belonging to the family Orthomyxoviridae ${ }^{32}$. The influenza A virus can be subdivided into different serotypes based on the antibody response to these viruses. The serotypes that have been confirmed in humans are H1N1, H1N2, H2N2, H3N2, H5N1, H7N2, H7N3, H7N7, H9N2, and H10N7. Some strains of H1N1 (a strain is a genetic variant or subtype) are endemic in humans. H1N1 strains caused a small percentage of all human flu infections in 2004-2005, while other strains are endemic in pigs (swine influenza) and in birds (avian influenza). In June 2009, the World Health Organization (WHO) declared a new strain of swine-origin H1N1 as a pandemic. This novel virus spread worldwide and had caused about 17,000 deaths by the start of 2010. On August 10, 2010, the WHO declared the H1N1 influenza pandemic over. Earlier in history, the Spanish flu, also known as La grippe, La Gripe Española, or La Pesadilla, was an unusually severe and deadly strain of avian influenza that killed some 50 to 100 million people worldwide over about a year during 1918 and 1919. It was one of the most deadly pandemics in humans up today ${ }^{33}$. In 1976, a novel swine influenza A (H1N1) caused severe respiratory illness in 13 soldiers with one death at Fort Dix (a US biological warfare military area), New Jersey USA. The virus did not spread beyond Fort Dix. It was demonstrated that more than 200 soldiers had been infected with the novel virus, which was a H1N1 strain. The cause of the outbreak is still unknown and no exposure to pigs was identified. The 1977-1978 Russian flu epidemic was caused by the strain influenza A/USSR/90/77 (H1N1). It attacked mostly children and young adults under 23 because, as a similar strain was prevalent in 1947-57, most adults had substantial immunity ${ }^{34}$. The spread and treatment of this disease is combated with vaccination and anti-influenza drugs. Several compounds targeting the virus neuraminidase have been synthesized, tested and approved for use in humans as anti-influenza agents ${ }^{35-37}$. Recently, a large group of angelicin derivatives was synthesized and tested as inhibitors of the influenza A/WSN/33 (H1N1) virus strain induced cytopathic effect ${ }^{38}$. When molecules are tested for their antiviral capacity, the results are reported as the concentration required to reduce the CPE by $50 \%$ related to a virus control. The selected molecules are shown in Fig. 1 and Table 1.

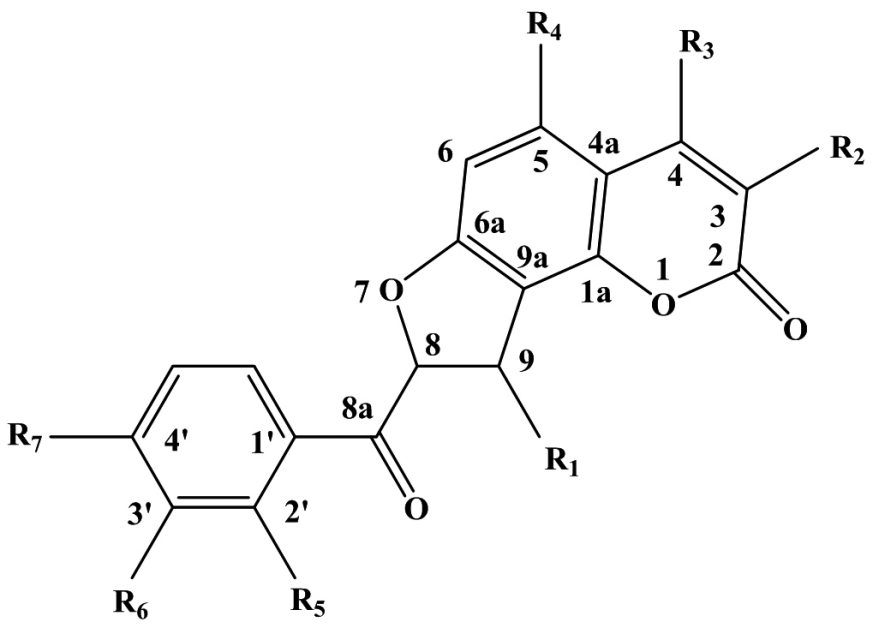

Figure 1. General formula of angelicin derivatives.

The other selected set is a group of indolarylsulfones acting as HIV-1 (the causative agent of AIDS) non-nucleoside reverse transcriptase (RT) inhibitors $(\text { NNRTIs) })^{39}$. Three kinds of results are reported in that work. The first is $\mathrm{EC}_{50}$, the effective concentration required to protect CEM cells (human T-lymphocyte cells) against the HIV-induced cytopathicity by $50 \%$ as monitoring by giant cell formation. The second result is $\mathrm{CC}_{50}$, defined as the concentration required reducing by $50 \%$ the number of viable cells in mock-infected CEM cultures. The last one is the in vitro HIV-1 RT inhibitory activities for several virus strains. We studied all three biological activities. The selected molecules are shown in Fig. 2 and Tables 2 and 3.

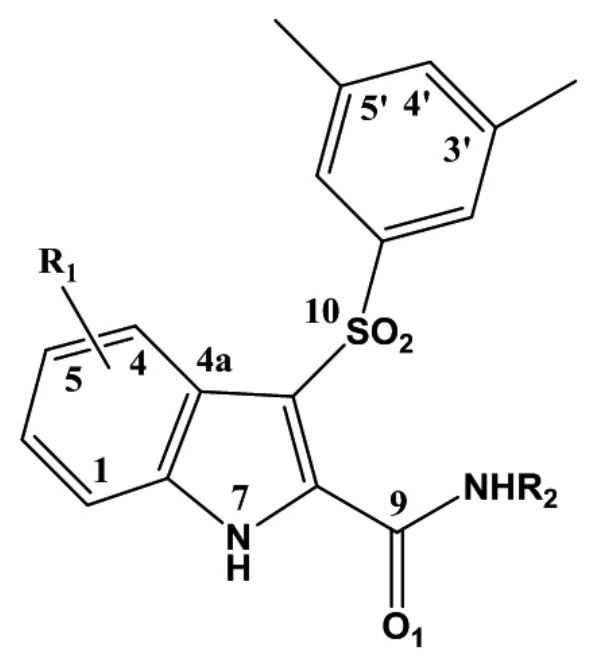

Figure 2. General formula of indolylarylsulfones derivatives. 
Table 1. Structures and experimental and calculated activities of angelicin derivatives.

\begin{tabular}{|c|c|c|c|c|c|c|c|c|}
\hline Molecule & $\mathrm{R}_{1}$ & $\mathrm{R}_{2}$ & $\mathrm{R}_{3}$ & $\mathrm{R}_{4}$ & $\mathrm{R}_{5}$ & $\mathrm{R}_{6}$ & $\mathrm{R}_{7}$ & exp. $\log \mathrm{IC}_{50}$ \\
\hline 1 & $\mathrm{Me}$ & $\mathrm{H}$ & $\mathrm{Me}$ & $\mathrm{H}$ & $\mathrm{H}$ & $\mathrm{H}$ & $\mathrm{H}$ & 0.65 \\
\hline 2 & $\mathrm{H}$ & $\mathrm{H}$ & $\mathrm{Me}$ & $\mathrm{H}$ & $\mathrm{H}$ & $\mathrm{H}$ & $\mathrm{H}$ & 0.39 \\
\hline 3 & $\mathrm{n}-\mathrm{Pr}$ & $\mathrm{H}$ & $\mathrm{Me}$ & $\mathrm{H}$ & $\mathrm{H}$ & $\mathrm{H}$ & $\mathrm{H}$ & -0.54 \\
\hline 4 & n-Hex & $\mathrm{H}$ & $\mathrm{Me}$ & $\mathrm{H}$ & $\mathrm{H}$ & $\mathrm{H}$ & $\mathrm{H}$ & -0.19 \\
\hline 5 & Phe & $\mathrm{H}$ & $\mathrm{Me}$ & $\mathrm{H}$ & $\mathrm{H}$ & $\mathrm{H}$ & $\mathrm{H}$ & -0.85 \\
\hline 6 & 1-naphthyl & $\mathrm{H}$ & $\mathrm{Me}$ & $\mathrm{H}$ & $\mathrm{H}$ & $\mathrm{H}$ & $\mathrm{H}$ & -0.06 \\
\hline 7 & 2-naphthyl & $\mathrm{H}$ & $\mathrm{Me}$ & $\mathrm{H}$ & $\mathrm{H}$ & $\mathrm{H}$ & $\mathrm{H}$ & 0.28 \\
\hline 8 & 2-thienyl & $\mathrm{H}$ & $\mathrm{Me}$ & $\mathrm{H}$ & $\mathrm{H}$ & $\mathrm{H}$ & $\mathrm{H}$ & -0.82 \\
\hline 9 & 2-furanyl & $\mathrm{H}$ & $\mathrm{Me}$ & $\mathrm{H}$ & $\mathrm{H}$ & $\mathrm{H}$ & $\mathrm{H}$ & -0.19 \\
\hline 10 & $4-\mathrm{CH}_{3}-\mathrm{Ph}$ & $\mathrm{H}$ & $\mathrm{Me}$ & $\mathrm{H}$ & $\mathrm{H}$ & $\mathrm{H}$ & $\mathrm{H}$ & -0.09 \\
\hline 11 & $4-\mathrm{CH}_{3} \mathrm{O}-\mathrm{Ph}$ & $\mathrm{H}$ & $\mathrm{Me}$ & $\mathrm{H}$ & $\mathrm{H}$ & $\mathrm{H}$ & $\mathrm{H}$ & 1.00 \\
\hline 12 & $4-\mathrm{NO}_{2}-\mathrm{Ph}$ & $\mathrm{H}$ & $\mathrm{Me}$ & $\mathrm{H}$ & $\mathrm{H}$ & $\mathrm{H}$ & $\mathrm{H}$ & -0.12 \\
\hline 13 & 4-Cl-Ph & $\mathrm{H}$ & $\mathrm{Me}$ & $\mathrm{H}$ & $\mathrm{H}$ & $\mathrm{H}$ & $\mathrm{H}$ & 0.59 \\
\hline 14 & $3-\mathrm{CH}_{3}-\mathrm{Ph}$ & $\mathrm{H}$ & $\mathrm{Me}$ & $\mathrm{H}$ & $\mathrm{H}$ & $\mathrm{H}$ & $\mathrm{H}$ & -1.00 \\
\hline 15 & $3-\mathrm{NO}_{2}-\mathrm{Ph}$ & $\mathrm{H}$ & $\mathrm{Me}$ & $\mathrm{H}$ & $\mathrm{H}$ & $\mathrm{H}$ & $\mathrm{H}$ & -0.60 \\
\hline 16 & 3-Cl-Ph & $\mathrm{H}$ & $\mathrm{Me}$ & $\mathrm{H}$ & $\mathrm{H}$ & $\mathrm{H}$ & $\mathrm{H}$ & 0.15 \\
\hline 17 & 3-CN-Ph & $\mathrm{H}$ & $\mathrm{Me}$ & $\mathrm{H}$ & $\mathrm{H}$ & $\mathrm{H}$ & $\mathrm{H}$ & -0.28 \\
\hline 18 & $\mathrm{Ph}$ & $\mathrm{H}$ & $\mathrm{H}$ & $\mathrm{H}$ & $\mathrm{H}$ & $\mathrm{H}$ & $\mathrm{H}$ & 1.25 \\
\hline 19 & $\mathrm{Ph}$ & $\mathrm{Me}$ & $\mathrm{H}$ & $\mathrm{H}$ & $\mathrm{H}$ & $\mathrm{H}$ & $\mathrm{H}$ & 0.45 \\
\hline 20 & $\mathrm{Ph}$ & $\mathrm{H}$ & $\mathrm{H}$ & $\mathrm{Me}$ & $\mathrm{H}$ & $\mathrm{H}$ & $\mathrm{H}$ & 0.89 \\
\hline 21 & $\mathrm{Ph}$ & $\mathrm{H}$ & $\mathrm{Et}$ & $\mathrm{H}$ & $\mathrm{H}$ & $\mathrm{H}$ & $\mathrm{H}$ & -0.62 \\
\hline 22 & $\mathrm{Ph}$ & $\mathrm{H}$ & $\mathrm{n}-\operatorname{Pr}$ & $\mathrm{H}$ & $\mathrm{H}$ & $\mathrm{H}$ & $\mathrm{H}$ & -0.33 \\
\hline 23 & $\mathrm{Ph}$ & $\mathrm{Me}$ & $\mathrm{Me}$ & $\mathrm{H}$ & $\mathrm{H}$ & $\mathrm{H}$ & $\mathrm{H}$ & -0.54 \\
\hline $24^{*}$ & $\mathrm{Ph}$ & $\mathrm{Me}$ & $\mathrm{H}$ & $\mathrm{H}$ & $\mathrm{H}$ & $\mathrm{H}$ & $\mathrm{H}$ & -0.14 \\
\hline $25^{* *}$ & $\mathrm{Ph}$ & $\mathrm{H}$ & $\mathrm{Me}$ & $\mathrm{H}$ & $\mathrm{H}$ & $\mathrm{H}$ & $\mathrm{H}$ & -0.49 \\
\hline $26^{* * *}$ & $\mathrm{Ph}$ & $\mathrm{H}$ & $\mathrm{Me}$ & $\mathrm{H}$ & $\mathrm{H}$ & $\mathrm{H}$ & $\mathrm{H}$ & -0.20 \\
\hline 27 & $\mathrm{Ph}$ & $\mathrm{H}$ & $\mathrm{Me}$ & $\mathrm{H}$ & $\mathrm{H}$ & $\mathrm{H}$ & $\mathrm{Me}$ & -0.06 \\
\hline 28 & $\mathrm{Ph}$ & $\mathrm{H}$ & $\mathrm{Me}$ & $\mathrm{H}$ & $\mathrm{H}$ & $\mathrm{H}$ & $\mathrm{OMe}$ & 0.22 \\
\hline 29 & $\mathrm{Ph}$ & $\mathrm{H}$ & $\mathrm{Me}$ & $\mathrm{H}$ & $\mathrm{H}$ & $\mathrm{H}$ & $\mathrm{Cl}$ & 1.35 \\
\hline 30 & $\mathrm{Ph}$ & $\mathrm{H}$ & $\mathrm{Me}$ & $\mathrm{H}$ & $\mathrm{Me}$ & $\mathrm{H}$ & $\mathrm{H}$ & -0.59 \\
\hline 31 & $\mathrm{Ph}$ & $\mathrm{H}$ & $\mathrm{Me}$ & $\mathrm{H}$ & $\mathrm{H}$ & $\mathrm{Me}$ & $\mathrm{H}$ & 0.82 \\
\hline 32 & $\mathrm{Ph}$ & $\mathrm{H}$ & $\mathrm{Me}$ & $\mathrm{H}$ & $\mathrm{OMe}$ & $\mathrm{H}$ & $\mathrm{H}$ & -0.96 \\
\hline 33 & $\mathrm{Ph}$ & $\mathrm{H}$ & $\mathrm{Me}$ & $\mathrm{H}$ & $\mathrm{H}$ & $\mathrm{OMe}$ & $\mathrm{H}$ & -0.19 \\
\hline 34 & $\mathrm{Ph}$ & $\mathrm{H}$ & $\mathrm{Me}$ & $\mathrm{H}$ & $\mathrm{NO}_{2}$ & $\mathrm{H}$ & $\mathrm{H}$ & 0.23 \\
\hline 35 & $\mathrm{Ph}$ & $\mathrm{H}$ & $\mathrm{Me}$ & $\mathrm{H}$ & $\mathrm{Cl}$ & $\mathrm{H}$ & $\mathrm{H}$ & -0.59 \\
\hline 36 & $\mathrm{Ph}$ & $\mathrm{H}$ & $\mathrm{Me}$ & $\mathrm{H}$ & $\mathrm{F}$ & $\mathrm{H}$ & $\mathrm{H}$ & -0.54 \\
\hline 37 & $\mathrm{Ph}$ & $\mathrm{H}$ & $\mathrm{Me}$ & $\mathrm{H}$ & $\mathrm{OH}$ & $\mathrm{H}$ & $\mathrm{H}$ & -0.14 \\
\hline 38 & $\mathrm{Ph}$ & $\mathrm{H}$ & $\mathrm{Me}$ & $\mathrm{H}$ & $\mathrm{O}-\mathrm{Et}$ & $\mathrm{H}$ & $\mathrm{H}$ & -0.92 \\
\hline 39 & $\mathrm{Ph}$ & $\mathrm{H}$ & $\mathrm{Me}$ & $\mathrm{H}$ & $\mathrm{O}-\mathrm{n}-\mathrm{Pr}$ & $\mathrm{H}$ & $\mathrm{H}$ & -0.82 \\
\hline 40 & $\mathrm{Ph}$ & $\mathrm{H}$ & $\mathrm{Me}$ & $\mathrm{H}$ & $\mathrm{O}-\mathrm{n}-\mathrm{Bu}$ & $\mathrm{H}$ & $\mathrm{H}$ & -1.10 \\
\hline 41 & $\mathrm{Ph}$ & $\mathrm{H}$ & $\mathrm{Me}$ & $\mathrm{H}$ & O-n-Pent & $\mathrm{H}$ & $\mathrm{H}$ & -0.85 \\
\hline 42 & $\mathrm{Ph}$ & $\mathrm{H}$ & $\mathrm{Me}$ & $\mathrm{H}$ & O-n-Oct & $\mathrm{H}$ & $\mathrm{H}$ & 0.90 \\
\hline 43 & $\mathrm{Ph}$ & $\mathrm{H}$ & $\mathrm{Me}$ & $\mathrm{H}$ & $\mathrm{O}\left(\mathrm{CH}_{2}\right)_{2} \mathrm{~N}(\mathrm{Me})_{2}$ & $\mathrm{H}$ & $\mathrm{H}$ & 0.72 \\
\hline 44 & $\mathrm{Ph}$ & $\mathrm{H}$ & $\mathrm{Me}$ & $\mathrm{H}$ & $\mathrm{O}\left(\mathrm{CH}_{2}\right)_{2} \mathrm{OH}$ & $\mathrm{H}$ & $\mathrm{H}$ & 0.78 \\
\hline 45 & $\mathrm{Ph}$ & $\mathrm{H}$ & $\mathrm{Me}$ & $\mathrm{H}$ & $\mathrm{O}\left(\mathrm{CH}_{2}\right)_{3} \mathrm{OH}$ & $\mathrm{H}$ & $\mathrm{H}$ & 0.42 \\
\hline
\end{tabular}

* With an $\mathrm{S}$ atom in position 7. ** With $\mathrm{OH}$ attached to $8 \mathrm{a}$. *** With $\mathrm{H}$ attached to 8a. 
J. Chil. Chem. Soc., 58, № 3 (2013)

Table 2. Structure and anti-HIV activity of Indolylarylsulfones in CEM cells.

\begin{tabular}{|c|c|c|c|c|}
\hline Molecule & $\mathrm{R}_{1}$ & $\mathrm{R}_{2}$ & $\begin{array}{c}\log \mathrm{EC}_{50} \\
\text { HIV-1 }\end{array}$ & $\log \mathrm{CC}_{50}$ \\
\hline 1 & $5-\mathrm{Cl}$ & & 0.52 & 1.04 \\
\hline 2 & $5-\mathrm{NO}_{2}$ & & 0.4 & 1.08 \\
\hline 3 & 4-F, 5-Cl & & 0.59 & 0.97 \\
\hline 4 & $5-\mathrm{Cl}$ & & 0.11 & 1 \\
\hline 5 & $5-\mathrm{NO}_{2}$ & & 0.49 & 1.08 \\
\hline 6 & 4-F, 5-Cl & & 0.59 & 1.51 \\
\hline 7 & $5-\mathrm{Cl}$ & & 0.28 & 1.04 \\
\hline 8 & $5-\mathrm{NO}_{2}$ & & 0.76 & 1.66 \\
\hline 9 & 4-F, 5-Cl & & 0.4 & 1.58 \\
\hline 10 & $5-\mathrm{Cl}$ & & 0.76 & 2.39 \\
\hline 11 & $5-\mathrm{NO}_{2}$ & & 0.79 & 0.9 \\
\hline 12 & 4-F, 5-Cl & & 0.76 & 1.18 \\
\hline 13 & $5-\mathrm{Cl}$ & & 1.23 & 0.85 \\
\hline 14 & $5-\mathrm{NO}_{2}$ & & 1.2 & 1.32 \\
\hline 15 & 4-F, 5-Cl & & 1.45 & 0.81 \\
\hline 16 & $5-\mathrm{Cl}$ & & 0.94 & 1.7 \\
\hline 17 & $5-\mathrm{NO}_{2}$ & & 0.9 & 1.62 \\
\hline 18 & 4-F, 5-Cl & & 1.11 & 1.04 \\
\hline 19 & $5-\mathrm{Cl}$ & & 0.76 & 2.27 \\
\hline 20 & $5-\mathrm{NO}_{2}$ & & 0.83 & --- \\
\hline 21 & 4-F, 5-Cl & & 1.15 & 1.23 \\
\hline 22 & $5-\mathrm{Cl}$ & & 0.81 & 1.73 \\
\hline 23 & $5-\mathrm{NO}_{2}$ & & 0.84 & 2.35 \\
\hline 24 & 4-F, 5-Cl & & 0.74 & 0.99 \\
\hline 25 & $5-\mathrm{Cl}$ & & 1.41 & 2.32 \\
\hline 26 & $5-\mathrm{NO}_{2}$ & & 1.46 & --- \\
\hline 27 & 4-F, 5-Cl & & 1.28 & 1.04 \\
\hline
\end{tabular}


TABLE 3. HIV-1 RT inhibitory activity against the Wild type and L1001 strains.

\begin{tabular}{|c|c|c|}
\hline Mol. & exp. $\log \mathrm{WT}$ & exp. $\log$ L100I \\
\hline 1 & 1.08 & 1.41 \\
\hline 2 & 1.53 & 1.73 \\
\hline 4 & 0.90 & 1.57 \\
\hline 5 & 1.11 & 1.00 \\
\hline 7 & 1.73 & 2.07 \\
\hline 8 & 2.18 & 2.00 \\
\hline 9 & 1.90 & 2.38 \\
\hline 10 & 1.32 & 1.18 \\
\hline 11 & 1.23 & 1.15 \\
\hline 12 & 1.60 & 1.60 \\
\hline 13 & 1.90 & 2.39 \\
\hline 14 & 2.45 & 2.77 \\
\hline 15 & 2.20 & 3.19 \\
\hline 16 & 2.00 & 2.35 \\
\hline 17 & 1.74 & 2.62 \\
\hline 18 & 2.85 & 2.87 \\
\hline 19 & 1.89 & 1.43 \\
\hline 20 & 1.78 & 1.60 \\
\hline 22 & 1.15 & 1.53 \\
\hline 23 & 1.53 & 1.36 \\
\hline 24 & 1.26 & 1.48 \\
\hline 25 & 3.38 & ---- \\
\hline 26 & 2.98 & ---- \\
\hline 27 & 1.82 & 1.83 \\
\hline
\end{tabular}

\section{Calculations.}

The calculation of the numerical values of the LARIs of Eq. 1 was carried out with Zerner's ZINDO/1 semiempirical method ${ }^{40-41}$. This choice is right because after geometry optimization ZINDO/1 is the only method producing positive nucleophilic superdelocalizabilities as required by the model ${ }^{42}$. As expected, ZINDO/1 gave good results when applied to the interaction of a group of 3-substituted morphinans with $\mu, \delta$ and $\kappa$ opioid receptors ${ }^{13}$, and for the inhibition of wild-type and drug-resistant HTV-1 reverse transcriptase by some thiazolidenebenzenesulfonamide derivatives ${ }^{43}$. It is worth of mention that, in general but not always, semiempirical methods give better QSAR results that HF or DFT ones ${ }^{7,11}$. We need to stress that, as we have shown during the last few years, the correct choice of more "primitive" methods (Extended Hückel Theory coupled with Molecular Mechanics) can be very useful in interpreting experimental results ${ }^{44-46}$.

The statistical fitting of equation 1 was performed by means of a Linear Multiple Regression Analysis (LMRA) with the logarithm of the corresponding biological activity value as the dependent variable and the local atomic reactivity indices of the atoms belonging to a common skeleton as independent variables. Hyperchem was employed for quantum-chemical calculations ${ }^{47}$. For linear multiple regression analysis we used the Statistica software ${ }^{48}$. Orientational parameters for the substituents were calculated as usual ${ }^{28-30}$.

\section{RESULTS AND DISCUSSION}

A. Reduction of the H1N1 influenza virus-induced cytopathic effects by angelicin derivatives.
No statistically significant equation was obtained for the whole set. We generated a subset comprising 35 molecules, all having a phenyl ring at position 11 (molecules 5, 10-24, 27-45 of Table 1). A preliminary LMRA showed that for molecule 31 the corresponding standard residual fell outside the \pm 2 sigma limit. Therefore we discarded it from the final set $(n=34$, Set I).

The best equation obtained for set I is:

$$
\begin{aligned}
& \log \mathrm{IC}_{50}=-7.02+31.46 \mathrm{~F}_{4}(\mathrm{HOMO})+0.44 \mathrm{~S}_{4^{\prime}}^{\mathrm{N}}+0.0004 \varphi_{5}+12.39 \mathrm{~F}_{8}(\mathrm{HOMO}-2)- \\
& -54.03 \mathrm{~F}_{1^{\prime}}(\mathrm{HOMO})+0.54 \mathrm{~S}_{4^{\prime}}^{\mathrm{E}}(\mathrm{HOMO}-1)+5.57 \mathrm{~F}_{\mathrm{O} 2}(\mathrm{LUMO}+2)- \\
& -5.13 \mathrm{~S}_{3^{\prime}}^{\mathrm{E}}(\mathrm{HOMO}-1)-5.21 \mathrm{~F}_{2}(\mathrm{HOMO}-1)
\end{aligned}
$$

with $\mathrm{n}=34, \mathrm{~F}(9,24)=27.158(\mathrm{p}<0.000001), \mathrm{R}^{2}=0.91$, outliers $>2 \mathrm{~S}=0$ and $\mathrm{SD}=0.25$. Here, $\mathrm{F}_{\mathrm{j}}(\mathrm{MO})$ refers to the non-zero Fukui index value for the $\mathrm{MO}$ located on atom $\mathrm{j}, \varphi_{5}$ is the orientational parameter of the substituent located at 2' position $\left(\mathrm{R}_{5}\right), \mathrm{S}^{\mathrm{N}}$ is the total atomic nucleophilic superdelocalizability of atom 1 and the sub index $\mathrm{O}_{2}$ refers to the $\mathrm{O}$ atom attached to position 2 . Tables 4 and 5 show, respectively, the results of the t-test for significance of coefficients and the matrix of squared correlation coefficients for the variables appearing in Eq. 7. Figure 3 displays the calculated vs. the observed values.

TABLE 4. Results of the t-test for significance of coefficients for the variables appearing in Eq. 7.

\begin{tabular}{|c|c|c|}
\hline Variable & $\mathrm{t}(24)$ & $\mathrm{p}$-level \\
\hline $\mathrm{F}_{4}(\mathrm{HOMO})$ & 10.98 & 0.0000001 \\
\hline $\mathrm{S}_{4}{ }^{\mathrm{N}}$ & 4.65 & 0.0001 \\
\hline$\varphi_{5}$ & 8.63 & 0.0000001 \\
\hline $\mathrm{F}_{8}(\mathrm{HOMO}-2)$ & 6.76 & 0.000001 \\
\hline $\mathrm{F}_{1},(\mathrm{HOMO})$ & -4.34 & 0.0002 \\
\hline $\mathrm{S}_{4}{ }^{\mathrm{E}}(\mathrm{HOMO}-1)$ & 5.09 & 0.00003 \\
\hline $\mathrm{F}_{\mathrm{O} 2}(\mathrm{LUMO}+2)$ & 4.74 & 0.00008 \\
\hline $\mathrm{S}_{3}{ }^{\mathrm{E}}(\mathrm{HOMO}-1$ & -5.25 & 0.00002 \\
\hline $\mathrm{F}_{2},(\mathrm{HOMO}-1)$ & -3.82 & 0.0008 \\
\hline
\end{tabular}

Figure 3. Plot of predicted vs. observed $\log \mathrm{IC}_{50}$ values from Eq. 7.

A very important point to stress is the following. When a local atomic index of a inner occupied MO (i.e., HOMO-1, HOMO-2, etc.) or of a higher empty $\mathrm{MO}$ (LUMO+1, LUMO+2, etc.) appears in any equation, this means that the remaining of the upper occupied MOs (for example, if HOMO-2 appears, upper means HOMO- 1 and HOMO) or the remaining of the empty MOs (for example, if LUMO+1 appears, lower means the LUMO) contribute to the interaction. Their absence in the equation only means that the variation of their numerical values does not account for the variation of the numerical value of the biological property. Note that, for example, HOMO-2, HOMO-1 and HOMO located on atom 8 seem to be involved in the process. Eq.7 shows that the variation of the reduction of H1N1 influenza virus-induced cytopathic effects is related to the variation of the values of a definite set of local atomic reactivity indices located mainly on the 2-benzoyl group on furan ring of the common skeleton (see Fig. 1). The action mechanism is clearly orbital-controlled ${ }^{49}$, but also has steric control through the orientational parameter. The occupied MOs located on atoms 4, 4', 8, 1', 3' and 2' interact with unoccupied MOs of one or more sites. The substituent's orientational parameter value should be high. The beta coefficients (not shown here) indicate that the importance of the variables is $\mathrm{F}_{4}(\mathrm{HOMO})>\mathrm{p}_{5}>\mathrm{F}_{8}(\mathrm{HOMO}-2)>\mathrm{S}_{3}^{\mathrm{E}}(\mathrm{HOMO}-1)>\mathrm{S}_{4}^{\mathrm{N}} \sim \mathrm{F}_{1}(\mathrm{HOMO}) \sim$ $\mathrm{S}^{\mathrm{E}}$ (HOMO-1) $\sim \mathrm{F}_{02}(\mathrm{LUMO}+2) \sim \mathrm{F}_{2}$ (HOMO-1). The results suggest that an ideal molecular system should have a carbonyl oxygen with enhanced H-bond capacity that could be modulated via the 4-substituent that must also improve the electron donor capacity of atom 4 . Atom 8 electron donor capacity could be enhanced manipulating the substituents of the phenyl ring attached to atom 9. The requirements for the other phenyl ring seem to be more complex and subtle. For example, the value of the substituent orientational parameter should be similar to the one for O-n-Pr. As the rest of the variables appearing in Eq. 7 and belonging to the aromatic ring are highly entangled it seems that the synthesis and testing of more angelicin derivatives coupled with higher-level calculations (HF or DFT) seem necessary. 
TABLE 5. Matrix of squared correlation coefficients for the variables appearing in Eq. 7.

\begin{tabular}{|c|c|c|c|c|c|c|c|}
\hline & $\begin{array}{c}\mathrm{F}_{4} \\
(\mathrm{HOMO})\end{array}$ & $\mathrm{S}_{4}{ }^{\mathrm{N}}$ & $\varphi_{5}$ & $\mathrm{~F}_{8}(\mathrm{HOMO}-2)$ & $\mathrm{F}_{1},(\mathrm{HOMO})$ & $\mathrm{S}_{4}{ }^{\mathrm{E}}(\mathrm{HOMO}-1)$ & $\mathrm{F}_{\mathrm{O} 2}(\mathrm{LUMO}+2)$ \\
\hline $\mathrm{F}_{4}(\mathrm{HOMO})$ & 1.0 & & & & & & \\
\hline $\mathrm{S}_{4}{ }^{\mathrm{N}}$ & 0.01 & 1.0 & & & & & \\
\hline$\varphi_{5}$ & 0.0008 & 0.05 & 1.0 & & & & \\
\hline $\mathrm{F}_{8}(\mathrm{HOMO}-2)$ & 0.003 & 0.07 & 0.16 & 1.0 & & & \\
\hline $\mathrm{F}_{1},(\mathrm{HOMO})$ & 0.4 & 0.12 & 0.001 & 0.14 & 1.0 & & \\
\hline $\mathrm{S}_{4}{ }^{\mathrm{E}}(\mathrm{HOMO}-1)$ & 0.03 & 0.08 & 0.02 & 0.001 & 0.03 & 1.0 & \\
\hline $\mathrm{F}_{\mathrm{O} 2}(\mathrm{LUMO}+2)$ & 0.01 & 0.04 & 0.02 & 0.005 & 0.09 & 0.16 & 1.0 \\
\hline $\left.\mathrm{S}_{3}{ }^{\mathrm{E}}, \mathrm{HOMO}-1\right)$ & 0.04 & 0.006 & 0.08 & 0.07 & 0.0009 & 0.06 & 0.01 \\
\hline
\end{tabular}

There are a couple of points to comment on. Given the way the $\mathrm{IC}_{50}$ values were measured and reported (addition of viruses mixed with the tested compounds, stain of the plates at the end of the experiment, washing, drying and density measurement at $570 \mathrm{~nm})^{38}$, it is very pleasant to see that the our results explain well a great quantity of experimental data, especially when it is known that the infectivity of influenza viruses differ among cell lines ${ }^{50}$. The importance of this result is more highlighted when we consider the proposed action mechanism of these compounds. Hsieh et al. suggest that the probable molecular target is the viral ribonucleoprotein $(\mathrm{RNP})^{33}$. During the viral life cycle, nucleoprotein binds with influenza viral RNA segments and polymerase subunit proteins to form virus ribonucleoprotein complex, which is transported to host cell nucleus to trigger viral RNA transcription, replication, and virion assembly ${ }^{51}$. As RNPs are located inside the virus it is logical to conclude that the tested molecules entered the virus before exerting their action. Then Eq. 7 should include one or more terms accounting for the passage of the tested compound to the interior of the virus and their interaction with viral RNP. We have not enough experimental data to assign by separate the terms appearing in Eq. 7 to each process. The structure of the QSAR equations reflects that these processes are very complex and selective due probably to the millions of years of evolution of the living matter.

Also we carried out a LMRA for the remaining molecules $(\mathrm{n}=10$, molecules 1-4, 6-9, 25-26 of Table 1, set II). The best statistical equation for this set is:

$$
\log \mathrm{IC}_{50}=1.31-3.39 \mathrm{~S}_{2^{\prime}}^{\mathrm{N}}(\mathrm{LUMO}+1)-0.73 \mathrm{~S}_{4^{\mathrm{E}}}^{\mathrm{E}}(\mathrm{HOMO})-17.85 \mathrm{~F}_{8 \mathrm{a}}(\mathrm{HOMO}-2)
$$

with $\mathrm{n}=10, \quad \mathrm{~F}(3,6)=40.494 \quad(\mathrm{p}<0.0002), \quad \mathrm{R}^{2}=0.95$, outliers $>2 \mathrm{~S}=0$ and $\mathrm{SD}=0.12$. Tables 6 and 7 show, respectively, the results of the t-test for significance of coefficients and the matrix of squared correlation coefficients for the variables appearing in Eq. 8. Figure 4 displays the calculated vs. the observed values. Like Eq. 7 the process is orbital-controlled. Beta coefficients (not shown) indicate that all variables have the same importance. The structure of Eq. 8 is similar to Eq. 7. It is interesting to note that here the variation of log $\mathrm{IC}_{50}$ is controlled by the variation of variables belong to only one aromatic ring and its adjacent carbon atom.

TABLE 6. Results of the t-test for significance of coefficients for the variables appearing in Eq. 8.

\begin{tabular}{|c|c|c|}
\hline Variable & $\mathrm{t}(6)$ & $\mathrm{p}$-level \\
\hline $\mathrm{S}_{2}{ }^{\mathrm{N}}(\mathrm{LUMO}+1)$ & -7.99 & 0.0002 \\
\hline $\mathrm{S}_{4}{ }^{ }{ }^{\mathrm{E}}(\mathrm{HOMO})$ & -7.65 & 0.0003 \\
\hline $\mathrm{F}_{8 \mathrm{a}}(\mathrm{HOMO}-2)$ & -5.50 & 0.0015 \\
\hline
\end{tabular}

TABLE 7. Matrix of squared correlation coefficients for the variables appearing in Eq. 8 .

\begin{tabular}{|c|c|c|}
\hline & $\mathrm{S}_{4}{ }^{\mathrm{E}}(\mathrm{HOMO})$ & $\mathrm{S}_{2}{ }^{\mathrm{N}}(\mathrm{LUMO}+1)$ \\
\hline $\mathrm{S}{ }^{\mathrm{E}}{ }^{ }(\mathrm{HOMO})$ & 1.0 & \\
\hline $\mathrm{S}_{2}{ }^{\mathrm{N}}(\mathrm{LUMO}+1)$ & 0.08 & 1.0 \\
\hline $\mathrm{F}_{8 \mathrm{a}}(\mathrm{HOMO}-2)$ & 0.42 & 0.34 \\
\hline
\end{tabular}

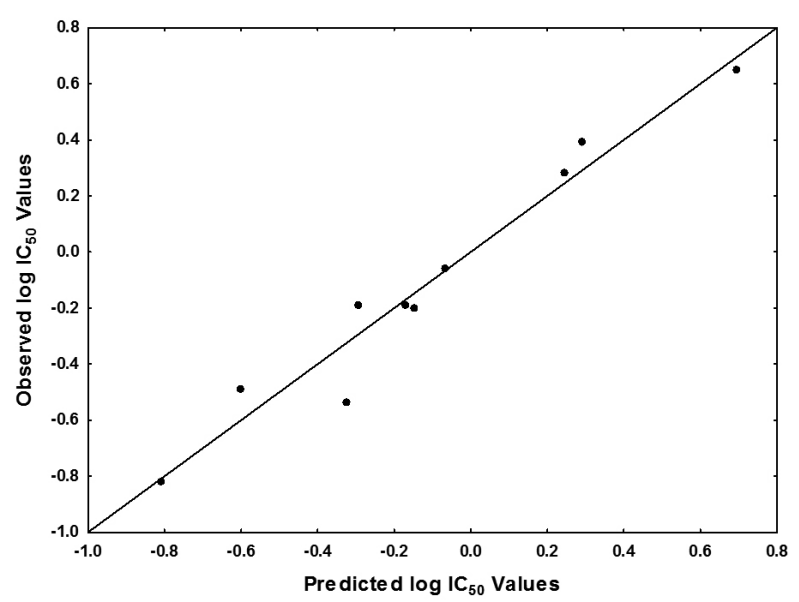

Figure 4. Plot of predicted vs. observed $\log \mathrm{IC}_{50}$ values from Eq. 8.

B. Inhibition of HIV-induced Cytopathicity by Indolylarylsulfones. was:

We selected 27 molecules, shown in Fig. 6 and Table 6. The best equation

$$
\begin{aligned}
& \log \mathrm{EC}_{50}=0.16+0.0004 \varphi_{1}-5.74 \mathrm{~S}_{\mathrm{O} 1}^{\mathrm{E}}(\mathrm{HOMO})+0.73 \mathrm{Q}_{4}- \\
& -1.04 \mathrm{~F}_{3^{\prime}}(\mathrm{HOMO}-2)+3.92 \mathrm{~S}_{5^{\prime}}^{\mathrm{E}}(\mathrm{HOMO})
\end{aligned}
$$

with $\mathrm{n}=27, \mathrm{~F}(5,21)=31.092(\mathrm{p}<0.000001), \mathrm{R}^{2}=0.88$, outliers $>2 \mathrm{~S}=0$ and $\mathrm{SD}=0.14$. Here, $\varphi_{1}$ is the orientational parameter of the $\mathrm{R}_{2}$ substituent, $\mathrm{Q}_{4}$ is the net charge of atom $4, \mathrm{~S}_{\mathrm{O} 1}{ }^{\mathrm{E}}(\mathrm{HOMO})$ is the orbital atomic electrophilic superdelocalizability of $\mathrm{O}_{1}$ oxygen atom, and so on (see Fig. 2). Tables 8 and 9 show, respectively, the results of the t-test for significance of coefficients and the matrix of squared correlation coefficients for the variables appearing in Eq. 9. Figure 5 displays the calculated vs. the observed values.

Eq. 4 is charge, orbital and steric-controlled. It is satisfactory to notice that the variation of $\log \mathrm{EC}_{50}$, i.e. the concentration required to protect CEM cells against the cytopathicity of HIV by $50 \%$ as monitored (with a microscope) by giant cell formation, can be accounted for by the variation of only four reactivity indices. The electronic reactivity indices are located on both aromatic systems, while the orientational effect belongs to the substituents attached to the $\mathrm{C}(\mathrm{O}) \mathrm{NH}$ moiety. Notice, for example, that three occupied MOs of atom 3' are involved in the process: HOMO, HOMO-1 and HOMO-2. The appearance of local atomic reactivity indices of 3' and 5' atoms in the 3-phenylsulphonyl moiety is in perfect agreement with the observation that methylation of these two carbon atoms expands the activity spectrum ${ }^{39}$. 
TABLE 8. Results of the t-test for significance of coefficients for the variables appearing in Eq. 9.

\begin{tabular}{|c|c|c|}
\hline Variable & $\mathrm{t}(21)$ & $\mathrm{p}$-level \\
\hline$\varphi_{1}$ & 8.43 & 0.0000001 \\
\hline $\mathrm{S}_{\mathrm{O} 1}{ }^{\mathrm{E}}(\mathrm{HOMO})$ & -4.77 & 0.0001 \\
\hline $\mathrm{Q}_{4}$ & 3.04 & 0.006 \\
\hline $\mathrm{F}_{3},(\mathrm{HOMO}-2)$ & -3.67 & 0.001 \\
\hline $\mathrm{S}_{5}{ }^{\mathrm{E}}(\mathrm{HOMO})$ & 2.46 & 0.023 \\
\hline
\end{tabular}

TABLE 9. Matrix of squared correlation coefficients for the variables appearing in Eq. 9.

\begin{tabular}{|c|c|c|c|c|}
\hline & $\mathrm{Q}_{4}$ & $\mathrm{~F}_{3},(\mathrm{HOMO}-2)$ & $\mathrm{S}_{5},{ }^{\mathrm{E}}(\mathrm{HOMO})$ & $\mathrm{S}_{\mathrm{O} 1}{ }^{\mathrm{E}}(\mathrm{HOMO})$ \\
\hline $\mathrm{Q}_{4}$ & 1.0 & & & \\
\hline $\mathrm{F}_{3},(\mathrm{HOMO}-2)$ & 0.02 & 1.0 & & \\
\hline $\mathrm{S}_{5}{ }^{\mathrm{E}}(\mathrm{HOMO})$ & 0.004 & 0.10 & 1.0 & \\
\hline $\mathrm{S}_{\mathrm{O} 1}{ }^{\mathrm{E}}(\mathrm{HOMO})$ & 0.18 & 0.002 & 0.005 & 1.0 \\
\hline$\varphi_{1}$ & 0.0 & 0.003 & 0.0009 & \\
\hline
\end{tabular}

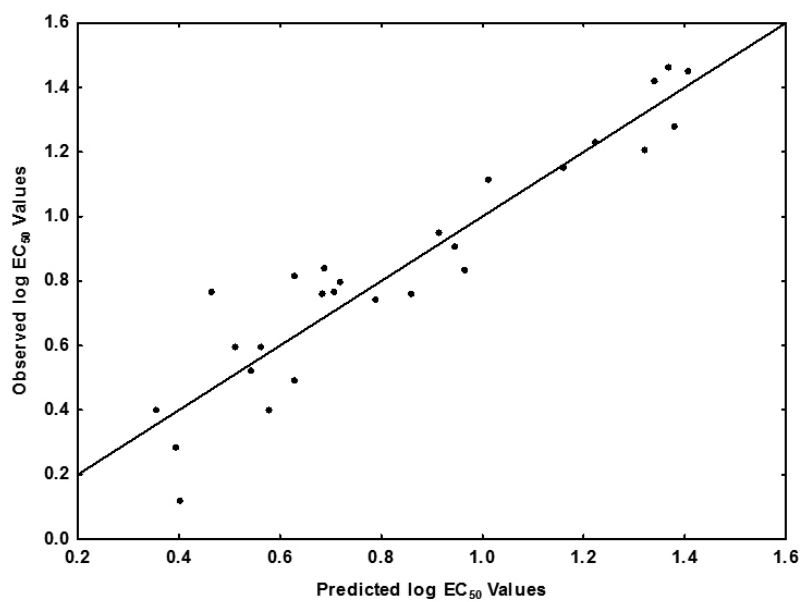

Figure 5. Plot of predicted vs. observed $\log \mathrm{IC}_{50}$ values from Eq. 9.

C. Cytostatic effects of indolylarylsulfones.

We selected 25 molecules, shown in Fig. 3 and Table 2. The best equation obtained is:

$$
\begin{aligned}
& \log \mathrm{CC}_{50}=2.16-11.82 \mathrm{~F}_{4 \mathrm{a}}(\mathrm{LUMO}+2)-2.41 \mathrm{~F}_{9}(\mathrm{LUMO})- \\
& -0.33 \mathrm{~S}_{5^{\prime}}^{\mathrm{E}}(\mathrm{HOMO}-2)+6.22 \mathrm{~F}_{9}(\mathrm{HOMO}-1)
\end{aligned}
$$

with $\mathrm{n}=25, \mathrm{~F}(4,20)=25.448(\mathrm{p}<0.0000001), \mathrm{R}^{2}=0.84$, outliers $>2 \mathrm{~S}=0$ and $\mathrm{SD}=0.22$. Tables 10 and 11 show, respectively, the results of the $\mathrm{t}$-test for significance of coefficients and the matrix of squared correlation coefficients for the variables appearing in Eq. 10. Figure 6 displays the calculated vs. the observed values. Here, the variation of $\log \mathrm{CC}_{50}$ is orbital-controlled with the participation of empty (LUMO, LUMO+1 and LUMO+2 located on atom 4a, LUMO located on atom 9) and occupied MOs (HOMO-1, HOMO-1 and HOMO located on atom 5', HOMO-1 and HOMO located on atom 9). As the detailed mechanism of this process is not known we cannot comment on the apparently contradictory appearance of occupied and empty MOs located on atom 9. Beta coefficients show that $\mathrm{F}_{4}(\mathrm{LUMO}+2)$ and $\mathrm{F}_{9}(\mathrm{LUMO})$ are more important than the other variables.
TABLE 10. Results of the t-test for significance of coefficients for the variables appearing in Eq. 10 .

\begin{tabular}{|c|c|c|}
\hline Variable & $\mathrm{t}(20)$ & $\mathrm{p}$-level \\
\hline $\mathrm{F}_{4 \mathrm{a}}(\mathrm{LUMO}+2)$ & -8.82 & 0.0000001 \\
\hline $\mathrm{F}_{9}(\mathrm{LUMO})$ & -6.18 & 0.000005 \\
\hline $\mathrm{S}_{5}{ }^{\mathrm{E}}(\mathrm{HOMO}-2)$ & -2.74 & 0.01 \\
\hline $\mathrm{F}_{9}($ HOMO-1 $)$ & 2.45 & 0.02 \\
\hline
\end{tabular}

TABLE 11. Matrix of squared correlation coefficients for the variables appearing in Eq. 10.

\begin{tabular}{|c|c|c|c|}
\hline & $\mathrm{F}_{4 \mathrm{a}}(\mathrm{LUMO}+2)$ & $\mathrm{S}_{5}{ }^{\mathrm{E}}($ HOMO-2 $)$ & $\mathrm{F}_{9}($ HOMO- $)$ \\
\hline $\mathrm{F}_{4 \mathrm{a}}(\mathrm{LUMO}+2)$ & 1.0 & & \\
\hline $\mathrm{S}_{5}{ }^{\mathrm{E}}(\mathrm{HOMO}-2)$ & 0.008 & 1.0 & \\
\hline $\mathrm{F}_{9}($ HOMO-1 $)$ & 0.006 & 0.004 & 1.0 \\
\hline $\mathrm{F}_{9}($ LUMO $)$ & 0.46 & 0.04 & 0.001 \\
\hline
\end{tabular}

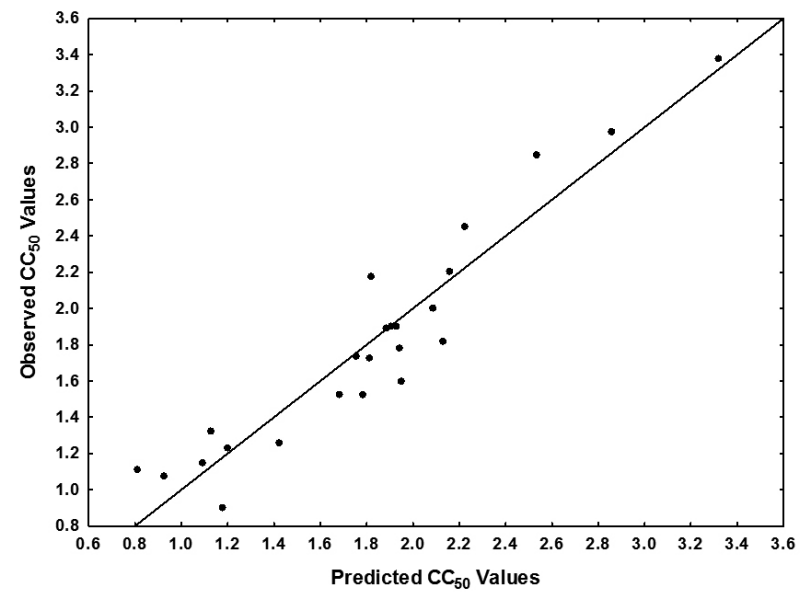

Figure 6. Plot of predicted vs. observed $\log \mathrm{IC}_{50}$ values from Eq. 10.

D. Inhibitory activity against Reverse Transcriptase (RT).

For the Wild Type (WT) strain the best equation obtained is:

$\log \mathrm{IC}_{50}=-16.38+0.001 \varphi_{1}-2.97 \mathrm{~S}_{\mathrm{Me}^{3}}^{\mathrm{N}}(\mathrm{LUMO}+2)-10.60 \mathrm{~F}_{9}(\mathrm{HOMO}-1)-$

$-1.87 \mathrm{~S}_{7}^{\mathrm{N}}(\mathrm{LUMO})-96.71 \mathrm{Q}_{7}+2.18 \mathrm{~F}_{10}(\mathrm{LUMO}+2)$

with $\mathrm{n}=24, \mathrm{~F}(4,20)=25.448(\mathrm{p}<0.0000001), \mathrm{R}^{2}=0.84$, outliers $>2 \mathrm{~S}=0$ and $\mathrm{SD}=0.22$. Tables 12 and 13 show, respectively, the results of the t-test for significance of coefficients and the matrix of squared correlation coefficients for the variables appearing in Eq. 11. Figure 7 displays the calculated vs. the observed values. Here, $\varphi$ represents the orientational parameter of the substituent attached to the $\mathrm{N}$ atom of the carboxamide moiety, $\mathrm{S}_{\mathrm{Me}^{\mathrm{N}}}^{\mathrm{N}}(\mathrm{LUMO}+2)$ is the orbital nucleophilic superdelocalizability of the LUMO+2 MO located on the methyl C carbon bonded to position 3', etc. (see Fig. 2). Beta coefficients indicate that the orientational parameter is the most important variable, followed by the net charge of atom 7 and the orbital nucleophilic superdelocalizability of the LUMO+2 MO located on the methyl $\mathrm{C}$ carbon. The inhibitory process is steric, charge and orbital-controlled. This result suggests that the common skeleton of all molecules binds in (almost) the same spatial position inside the non-nucleoside binding site of the reverse transcriptase. It has been suggested that there is an H-bond interaction between the nitrogen atom in the carboxamide chain of indoarylsulfones and a carboxylic counterpart in the RT. Our results draw attention to the electrondonating capacity of the carbon atom of this moiety and on the electronaccepting capacity of the sulphur atom. 
TABLE 12. Results of the t-test for significance of coefficients for the variables appearing in Eq. 11 (Wild type strain).

\begin{tabular}{|c|c|c|}
\hline Variable & $\mathrm{t}(17)$ & $\mathrm{p}$-level \\
\hline$\varphi_{1}$ & 10.04 & 0.0000001 \\
\hline $\mathrm{Me}_{3}$, & -6.36 & 0.000007 \\
\hline $\mathrm{F}_{9}(\mathrm{HOMO}-1)$ & -4.07 & 0.0008 \\
\hline $\mathrm{S}_{7}^{\mathrm{N}}(\mathrm{LUMO})$ & -5.17 & 0.00008 \\
\hline $\mathrm{Q}_{7}$ & -4.80 & 0.0002 \\
\hline $\mathrm{F}_{10}(\mathrm{LUMO}+2)$ & 3.56 & 0.002 \\
\hline
\end{tabular}

TABLE 13. Matrix of squared correlation coefficients for the variables appearing in Eq. 11 (Wild type strain).

\begin{tabular}{|c|c|c|c|c|c|}
\hline & $\mathrm{Q}_{7}$ & $\begin{array}{c}\mathrm{S}_{7}^{\mathrm{N}} \\
(\mathrm{LUMO})\end{array}$ & $\begin{array}{c}\mathrm{F}_{10} \\
\left(\mathrm{LUMO}^{2}\right)\end{array}$ & $\mathrm{Me}_{3}$, & $\begin{array}{c}\mathrm{F}_{9} \\
(\mathrm{HOMO}- \\
1)\end{array}$ \\
\hline $\mathrm{Q}_{7}$ & 1.0 & & & & \\
\hline $\mathrm{S}_{7}{ }^{\mathrm{N}}(\mathrm{LUMO})$ & 0.03 & 1.0 & & & \\
\hline $\mathrm{F}_{10}(\mathrm{LUMO}+2)$ & 0.08 & 0.15 & 1.0 & & \\
\hline $\mathrm{Me}_{3}$, & 0.31 & 0.005 & 0.005 & 1.0 & \\
\hline $\mathrm{F}_{9}(\mathrm{HOMO}-1)$ & 0.02 & 0.004 & 0.006 & 0.002 & 1.0 \\
\hline$\varphi_{1}$ & 0.29 & 0.15 & 0.07 & 0.02 & 0.10 \\
\hline
\end{tabular}

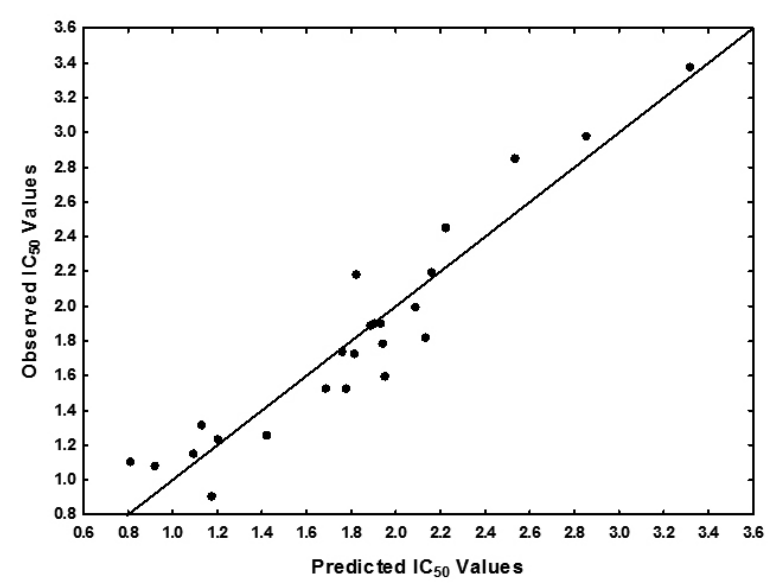

Figure 7. Plot of predicted vs. observed $\log \mathrm{IC}_{50}$ values from Eq. 11 (Wild type strain).

For the L100I strain the best equation obtained is:

$\log \mathrm{IC}_{50}=-8.88+12.99 \frac{1}{\eta_{5^{\prime}}}-7.74 \frac{1}{\eta_{4^{\prime}}}+0.0005 \varphi_{1}-3.77 \mathrm{~F}_{1}(\mathrm{HOMO}-1)-$
$-0.12 \mathrm{~S}_{\mathrm{OS}}^{\mathrm{E}}(\mathrm{HOMO}-2)$

with $\mathrm{n}=22 . \mathrm{F}(5,16)=25.568(\mathrm{p}<0.000001), \mathrm{R}^{2}=0.85$, outliers $>2 \mathrm{~S}=0$ and $\mathrm{SD}=0.23$. Tables 14 and 15 show, respectively, the results of the t-test for significance of coefficients and the matrix of squared correlation coefficients for the variables appearing in Eq. 12. Figure 8 displays the calculated vs. the observed values. Here $\eta_{,}$, is the local atomic hardness of atom $5^{\prime}\left(1 / \eta_{,}\right.$, is the local atomic softness of atom 5'), $\mathrm{S}_{\mathrm{OS}}{ }^{\mathrm{E}}(\mathrm{HOMO}-2)$ is the orbital electrophilic superdelocalizability of the oxygen atom of the $\mathrm{SO}_{2}$ group, etc. (see Fig. 2). Beta coefficients (not shown here) indicate that the most important variables are the local atomic softness of atoms 4' and 5'. This is the first time that this specific reactivity index appears in a model-based equation ${ }^{7}$. Eq. 12 is steric and orbital-controlled and presents some resemblances with Eq. 11. Both contain the same orientational parameter, reactivity indices located on atoms of the carboxamide moiety and on atom 5' or its methyl carbon atom. Interestingly the softness, a positive number, exerts opposite actions on the inhibitory activity (shown by the opposite signs of the coefficients). L100I is a mutation from leucine (L) to isoleucine(I) at position 100. Is was suggested that the L100I mutation is likely to inflict a steric penalty or to destabilize the H-bond of some NNRTIs to Lys $101^{52,53}$. This fact is not reflected in the QSAR equation. The region comprising atoms 3', 4' and 5' seems to be fundamental for the interaction of the Wild type and L100I mutation to RT.

TABLE 14. Results of the t-test for significance of coefficients for the variables appearing in Eq. 12 (L100I strain).

\begin{tabular}{|c|c|c|}
\hline Variable & $\mathrm{t}(16)$ & $\mathrm{p}$-level \\
\hline $1 / \eta_{4}$, & 9.56 & 0.0000001 \\
\hline $1 / \eta_{5}$, & -5.28 & 0.00007 \\
\hline$\varphi_{1}$ & 5.60 & 0.00004 \\
\hline $\mathrm{F}_{1}(\mathrm{HOMO}-1)$ & -3.82 & 0.0015 \\
\hline $\mathrm{S}_{\mathrm{O}}{ }^{\mathrm{E}}(\mathrm{HOMO}-2)$ & -2.60 & 0.019 \\
\hline
\end{tabular}

TABLE 15. Matrix of squared correlation coefficients for the variables appearing in Eq. 12 (L100I strain).

\begin{tabular}{|c|c|c|c|c|}
\hline & $\begin{array}{c}\mathrm{F}_{1} \\
\text { HOMO-1 })\end{array}$ & $1 / \eta_{4}$, & $1 / \eta_{5}$, & $\begin{array}{c}\mathrm{S}_{\mathrm{O}}{ }^{\mathrm{E}} \\
(\text { HOMO-2) }\end{array}$ \\
\hline $\mathrm{F}_{1}(\mathrm{HOMO}-1)$ & 1.0 & & & \\
\hline $1 / \eta_{4}$, & 0.18 & 1.0 & & \\
\hline $1 / \eta_{5}$, & 0.09 & 0.55 & 1.0 & \\
\hline $\mathrm{S}_{\mathrm{O}}{ }^{\mathrm{E}}(\mathrm{HOMO}-2)$ & 0.004 & 0.05 & 0.0008 & 1.0 \\
\hline$\varphi_{1}$ & 0.05 & 0.006 & 0.003 & 0.04 \\
\hline
\end{tabular}

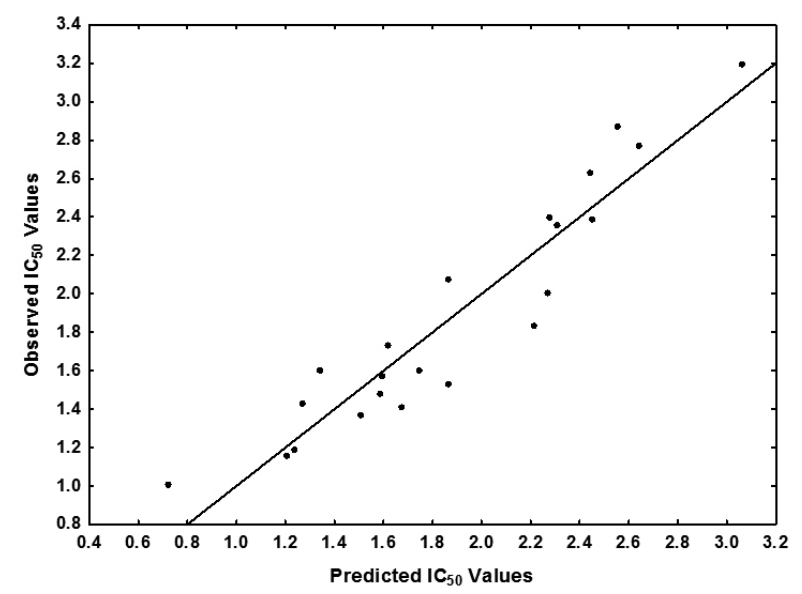

Figure 8. Plot of predicted vs. observed $\log \mathrm{IC}_{50}$ values from Eq. 12 (L100I strain).

No statistically significant equation could be obtained for the K103N strain. In K103N, we have a mutation at codon 103 in HIV's RT gene. In that particular spot, the amino acid $\mathrm{K}$ (lysine) has been replaced by the amino acid $\mathrm{N}$ (asparagine). K103N makes HIV-1 highly resistant to many of the approved drugs of the NNRTI class. For this case, it is interesting to note that several $\mathrm{IC}_{50}$ values are very high $(6682,10390 \text { and } 18500 \mathrm{nM})^{39}$. We are not sure if that these values are real inhibition constants or represent more than one process. The other possibility is that a subset of the analyzed molecules binds in a different way to $\mathrm{RT}^{54}$. Y181I strain was not analyzed because not enough experimental data was available.

\section{CONCLUSIONS}

The main and most important conclusion is that the method, originally designed for in vitro molecule-site equilibrium constants, nicely works for other properties like cytopathicity protection and cytostatic concentrations. This opens an entirely new research field and raises the possibility that this methodology be applied to other types of measurements of biological activity ${ }^{55}$. 
We conjecture that probably this method is superior to the Hansch approach and is related in a still unknown form to the Hammett methodology. The new local atomic reactivity indices appear in one equation, suggesting their utility in future QSAR studies.

\section{REFERENCES}

1. F. Peradejordi, A.N. Martin, A. Cammarata, J. Pharm. Sci., 60, 576 (1971).

2. J.S. Gómez-Jeria, Int. J. Quant. Chem., 23, 1969 (1983).

3. J.S. Gómez-Jeria, in Molecules in Physics, Chemistry and Biology Vol. IV, J. Maruani Ed. Kluwer Academic Publishers, Holland, 1989; pp. 215231.

4. J.S. Gómez-Jeria, D. Morales-Lagos, J. Pharm. Sci., 73, 1725 (1984).

5. J.S. Gómez-Jeria, M. Ojeda-Vergara, J. Chil. Chem. Soc., 48, 119 (2003).

6. A. Cammarata, J. Med. Chem., 11, 1111 (1968).

7. T. Bruna-Larenas and J. S. Gómez-Jeria, Intern. J. Med. Chem., 2012 Article ID 682495, pp. 16 (2012). doi:10.1155/2012/682495.

8. S.B. Hamilton, D.E. Wyatt, B.T. Wahlgren, M.K. O’Dowd, J.M. Morrissey, D.E. Daniels, J.A. Lednicky, Virology Journal, 8, 66 (2011).

9. J.M. Costin, Virology Journal, 4, 100 (2007).

10. Y.C. Martin. Quantitative Drug Design. A critical Introduction. Dekker, New York, 1978.

11. J.S. Gómez-Jeria, J. Chil. Chem. Soc., 55, 381 (2010).

12. J.S. Gómez-Jeria, F. Soto-Morales, J. Rivas, A. Sotomayor, J. Chil. Chem. Soc., 53, 1382 (2008).

13. J.S. Gómez-Jeria, L.A. Gerli-Candia, S.M. Hurtado, J. Chil. Chem. Soc. 49, 307 (2004).

14. F. Soto-Morales, J.S. Gómez-Jeria, J. Chil. Chem. Soc., 52, 1214 (2007).

15. J.S. Gómez-Jeria, D. Morales-Lagos, B.K. Cassels, J.C. SaavedraAguilar, Quant. Struct.-Act. Relat. 5, 153 (1986).

16. J.S. Gómez-Jeria, M. Ojeda-Vergara, Int. J. Quant. Chem. 61, 997 (1997).

17. J.S. Gómez-Jeria, B.K. Cassels, J.C. Saavedra-Aguilar, Eur. J. Med. Chem. 22, 433 (1987).

18. K. Fukui, T. Yonezawa, C. Nagata, Bull. Chem. Soc. Japan, 27, 423 (1954).

19. R. G. Parr, W. Yang, Ann. Rev. Phys. Chem., 46, 701 (1995).

20. H. Chermette, J. Comp. Chem., 20, 129 (1999).

21. P. Geerlings, F.De Proft, W. Langenaeker, Chem. Rev., 103, 1793 (2003).

22. P. W. Ayers, J. S. M. Andersin, L. J. Bartolotti, Int. J. Quant. Chem., 101, $520(2005)$.

23. J. L. Gázquez, J. Mex. Chem. Soc., 52, 3 (2008).

24. S. B. Liu, Acta Physico-Chim. Sinica (Wuli Huaxue Xuebao), 25, 590 (2009).

25. A. Cammarata, K.S. Rogers, J. Med. Chem. 14, 269 (1971).

26. K.S. Rogers, A Cammarata, Biochim. Biophys. Acta (BBA), 193, 22 (1969).

27. K.S. Rogers, A, Cammarata, J. Med. Chem., 12, 692 (1969).

28. M. Ojeda-Vergara, MSc Thesis (Chemistry), University of Chile, Faculty of Sciences, 1991.

29. J. S. Gómez-Jeria, M. Ojeda-Vergara and C. Donoso-Espinoza, Mol. Eng., 5, 391 (1995) 401.

30. J. S. Gómez-Jeria, M. Ojeda-Vergara, J. Chil. Chem. Soc., 48, 119 (2003).

31. E. L. Plummer, The application of Quantitative design strategies in Pesticide discovery, in: Reviews in Computational Chemistry, Vol. 1, K.B. Lipkowitz and D. B. Boyd, Eds, Wiley-VCH, New York, 1990, pp. 134-168.

32. B.W.J. Mahy, M. H.V. van Regenmortel (Eds.), Encyclopedia of Virology, $3^{\text {rd }}$ edition, Academic Press, New York, 2008. B.W.J. Mahy, M. H.V. van Regenmortel (Eds.), Desk Encyclopedia of Human and Medical Virology, Elsevier/Academic Press, Amsterdam, 2010. B.W.J. Mahy, A Dictionary of Virology, Harcourt Publishers, San Diego, 2001.

33. G. C. Kohn, Ed., Encyclopedia of plague and pestilence from ancient times to the present. Third Ed., Infobase Publishing, New York, 2007.

34. A. P. Kendal, G. R. Noble, J. J. Skehel, W. R. Dowdle, Virology, 89, 632 (1978).

35. Y. Liua, F. Jingb, Y. Xua, Y. Xiea, F. Shia, H. Fanga, M. Lia, W. Xua, Bioorg. Med. Chem., 19, 2342 (2011).

36. H. Shikawa, T. Suzuki, H. Orita, T. Uchimaru, Y. Hayashi, Chem. Eur. J., 16, 12616 (2010). Corrigendum: 17, 12227 (2010).

37. J. Kongkamnerd, L. Cappelletti, A. Prandi, P. Seneci, T. Rungrotmongkol, N. Jongaroonngamsang, P. Rojsitthisak, V. Frecer, A. Milani, G. Cattoli,
C. Terregino, I. Capua, L. Beneduce, A. Gallotta, P. Pengo, G. Fassina, S. Miertus, W. De-Eknamkul, Bioorg. Med. Chem., 20, 2152 (2012).

38. J-H. Yeh, M. S. Coumar, J-T. Horng, H-Y. Shiao, F-M. Kuo, H-L Lee, I-C. Chen, C-W. Chang, W-F. Tang, S-N. Tseng, C-J. Chen, S-R. Shih, J. T-A. Hsu, C-C. Lian, Y-S. Chao, H-P. Hsieh, J. Med. Chem. 53, 1519 (2010).

39. G. La Regina, A. Coluccia, A. Brancale, F. Pisticelli, V. Gatti, G. Maga, A. Samuele, C. Pannecuoque, D. Schols, J. Balzarini, E. Novellino, R. Silvestri, J. Med. Chem. 54, 1587 (2011).

40. W.D. Edwards, M.C. Zerner, Theoret. Chim. Acta, 72, 347 (1987).

41. W.P. Anderson, W.D. Edwards, M.C. Zerner, Inorg. Chem, 28, 2728 (1986).

42. J.S. Gómez-Jeria, J. Pharm. Sci. 71, 1423 (1982).

43. F. Soto-Morales, J.S. Gómez-Jeria, J. Chil. Chem. Soc., 52, 1214 (2007).

44. J.S. Gómez-Jeria, J. Comp. Theoret. Nanosci., 6, 1361 (2009).

45. A. E. Aliaga, H. Ahumada, K. Sepúlveda, J.S. Gómez-Jeria, B. WeissLópez, M.M. Campos-Vallette, J. Phys. Chem. C, 115, 3982 (2011).

46. C. Garrido, A. E. Aliaga, J. S. Gómez-Jeria, J. J. Cárcamo, E. Clavijo, M. M. Campos-Vallette, Vib. Spectr., 61, 94 (2012).

47. Hyperchem. Hypercube, Inc. 1115 NW 4th St. Gainesville, FL 32608 (USA).

48. Statistica. StatSoft, Inc. 2300 East 14th St. Tulsa, OK 74104 (USA).

49. G. Klopman, The Generalized Perturbation Theory of Chemical Reactivity and its Applications, in G. Klopman, Ed., Chemical Reactivity and Reaction Paths, Wiley-Interscience, New York, 1974, pp. 55-165.

50. S.B Hamilton, D.E Wyatt, B.T Wahlgren, M. K O’Dowd, J. M Morrissey, D.E Daniels, J.A. Lednicky, Virology J., 8, 66 (2011).

51. J. Du, T.A. Cross, H-X. Zhou, Drug Discovery Today, 17, 1111 (2012).

52. W. De-Ping, R.C. Rizzo, J. Tirado-Rives, W.L: Jorgensen, Bioorg. \& Med. Chem. Lett., 11, 2799 (2001).

53. K. Das, A.D. Clark, Jr., Y.V. Frenkel, P.J. Lewi, A.J. Shatkin, S.H. Hughes, E. Arnold, Proc.Natl. Acad. Sci. USA, 105, 1466 (2008).

54. K. Singh, B. Marchand, K.A. Kirby, E. Michailidis S.G. Sarafianos, Viruses, 2, 606 (2010)

55. C. Barahona-Urbina, S. Nuñez-Gonzalez, J.S. Gómez-Jeria, J. Chil. Chem. Soc., 57, 1497 (2012). 